\title{
POLITICAL BUDGET CYCLES IN MUNICIPALITIES: EVIDENCE FROM INDONESIA
}

\author{
Doddy Setiawan* \\ Universitas Sebelas Maret \\ Farah Rizkiah \\ Universitas Sebelas Maret
}

\begin{abstract}
This study aims to examine the presence of politically induced and electorally motivated economic policy in local government budget. Further, the study examine the presence of pre-electoral manipulation through the behavior of budget balance, total expenditures, investment expenditures, and other administrative expenditures including donations, social assistance, and financial assistance expenditure during election year. Samples of the study consists of 451 district municipalities in Indonesia which held direct local elections over the period 2010-2014. The result of the study shows an opportunistic PBC pattern in the budget balance, total expenditures, donation expenditures, and financial assistance expenditures. The result suggest that there is an increase in local budget deficit in election years. Total expenditures also seem to increase during the election year, along with donation and financial assistance expenditures. This result supports the notion that elections have a positive effect on the government expenditures through the increase of municipal expenditures, especially expenditures that are highly visible to electorate.
\end{abstract}

Keywords: Political Budget Cycles; Municipalities; Budget Balance; Local Election.

\section{INTRODUCTION}

Since the fall of the New Order regime, Indonesia has paved the path of decentralization through the implementation of Law No. 22 of 1999 on regional autonomy law and Law No. 25 of 1999 on fiscal balance between the center and the regions. One of the most important reforms implemented is the adoption of direct democratic local elections for both executive and legislative posts. Since 2005, direct local executive elections have been held in all 33 provinces and the 500 or so districts and municipalities in Indonesia. On average, over 100 subnational elections have been run annually, with the ordinary Indonesian voting in seven or eight separate ballots between 2004 and 2009 alone (Gunawan \& Siregar, 2009).

However, direct local election becomes a heated competition between local powerful figures, sometimes including the current office holder, who are determined to do whatever it takes to win, and even use desperate measures that include electoral fraud, buying votes, and mobilizing protests. This problem is visible in particular among the regional elections in which there are incumbents. There is a common perception that incumbents often try to use economic policy to increase their re-election chances. According to Nordhaus (1975), incumbents have strong incentives to affect voters' behavior by using fiscal policy, the more so if elections are at hand and voters base their behavior on the recent past.

\footnotetext{
- Corresponding author: Doddy Setiawan, Faculty of Economics and Business, Universitas Sebelas Maret, J1 Ir Sutami No.36A, Surakarta, Indonesia 57126, telp: 62.271.647481, email: doddy.setiawan@staff.uns.ac.id
} 
Since voters are expected to evaluate the candidate they vote on the basis of past track record, the executive who has full discretion over fiscal policy could purposely allocate government spending at strategically important time points during their tenure to give good impression to people and enhance the prospect of their re-election. This discretionary spending is usually budgeted as donation (hibah), social assistance (dana bantuan sosial), or other financial assistance to lower regions (sub-districts or villages).

Previous study on the political budget cycle conducted by Alesina and Paradisi (2017), Balaguer-Coll, Brun-Martos, Forte, and Tortosa-Ausina (2015), Chortareas, Logothetis, and Papandreou (2016), Klomp and De Haan (2013a, 2013b) and Sjahrir, Kis-Katos, and Schulze (2013). These study shows that political budget exist. Further, Klomp and De Haan (2013a) argue that political budget cycle conditional on the country condition such as development and democracy and the quality of the government. Political budget cycles more likely exist in the developing country rather than developed country (De Haan \& Klomp, 2013). This study shows the importance to analyze the political budget cycles using different institutional context. Indonesia provide unique setting to analyze political budget cycle study because Indonesia adopt direct election for both legislative and executive post. Previous study on political budget cycle in Indonesia are rare except Sjahrir et al. (2013). They find that political budget cycles exist at the local level, especially in direct election and the discretionary spending. However, Winoto and Falikhatun (2015) find no significant misuse of discretionary fund before local election at 2015. Therefore, this study investigate the political budget cycles at municipalities' level using Indonesian context. In this study, the presence of pre-electoral manipulation is examined through increased government expenditures by reviewing the behavior of budget balance, total expenditures, investment expenditures, and other administrative expenditures including donations, social assistance, and financial assistance expenditure during election year. This study examines the presence of these politically induced and electorally motivated economic policy in local government budget, focusing on 451 districts and municipalities in Indonesia which held direct local elections over the period 20102014.

\section{REVIEW OF LITERATURE AND HYPHOTESIS DEVELOPMENT}

Political Budget Cycles (PBC) is defined as the possibility of a macroeconomic cycles induced by the political cycles. The theory is first introduced by Nordhaus (1975) who proposed a model in which incumbents would manipulate the macroeconomic policy to gain electoral advantages, by assuming that electorate votes retrospectively, so incumbents attempt to create the most desirable economic conditions before elections by engaging in expansionary fiscal policies to stimulate economy and generate "favorable" conditions to gain electoral advantages.

More recent literatures, such as Rogoff and Sibert (1988), Persson and Tabellini (2002) and Shi and Svensson (2006) assume that voters have rational expectations, however suffer from asymmetric information regarding the incumbent's competence level. In this recent models, signaling is the driving force behind the political budget cycles. Incumbents use government spending to increase macroeconomic performance in pre-election periods in an effort to signal competence.

Previous research support that political budget cycles indeed occur, even though opinions still differ as to whether political budget cycles are more likely happened in less developed economies compared to developing ones (Brender \& Drazen, 2005; Persson \& Tabellini, 2002; Shi \& Svensson, 2006). Alt, Lassen, and Wehner (2014) provide evidence that political budget cycles exist in Europe. 
While recent studies identify several PBC determinants at the national level, there is growing literature considering political budget cycles at the local level where greater homogeneity in government structure, available policy instruments, and uniformity in electoral rules and dates are present (Chortareas et al., 2016). The studies to examine the evidence of political budget cycles on local election has generated mixed results (Klomp \& De Haan, 2013b). Brender (2003) does not find robust result using data for Israel, while Drazen and Eslava (2010) find evidence in Columbian municipalities that a pre-electoral increase in targeted expenditures affect electorates behavior. Akhmedov and Zhuravskaya (2004) consider Russian provinces and show evidence of an increase transfers to electorates before elections.

In local governments in Indonesia, Ritonga and Alam (2010) find that the allocation of grant and society support expenditure in incumbent regions during the elections year is higher than prior the elections. Sjahrir et al. (2013) analyze the political budget cycles effect for indirect and direct elections in Indonesia and find that significant political budget cycles exist in Indonesian districts only for direct, not for indirect election, and that the political budget cycles are significantly stronger when incumbents run for reelection. Winoto and Falikhatun (2015) investigate the possibility of misuse of discretionary funds in local governments' budget, but found no indication of misuse of grant and social aid before the local election in 2015.

In this study, the presence of pre-electoral manipulation is examined through increased government expenditures by reviewing the behavior of budget balance, total expenditures, investment expenditures, and other administrative expenditures including donations, social assistance, and financial assistance expenditure during election year. The underline assumption on the theoretical framework of political budget cycle is that an incumbent's reelection chances can be increased by expansionary fiscal policy in general, and in election years in particular (Brender \& Drazen, 2008). Rogoff (1990) argues that expansionary fiscal policy during election years could lead electorates to vote for incumbents who produce them because it signals high competence.

Theoretical model developed by Rogoff and Sibert (1988) explains the existence of political budget cycles with rational electorates who suffer from asymmetric information regarding the competencies of elected officials. In this context, incumbents would engage in electoral cycles by manipulating economic policy variables, such as taxes and government expenditures, to produce a given level of public services with a lesser amount of revenue as a way to signal competence to electorates.

Vergne (2009) find evidence that election-year public spending shifts toward more visible current expenditures, in particular wages and subsidies. In line with that, other study focusing on the analysis of local units (Akhmedov \& Zhuravskaya, 2004; Galli \& Rossi, 2002) identify increases in total expenditures and various spending category such as health care, educational, and road construction in election years. Labonne (2016) investigate the effect of election year on the level of employment using Philippines sample. The result shows that level of employment is increase before the election year and decrease after that. This result confirm the expectation that local government use their discretion to increase the popularity to win the election.

Veiga and Veiga (2007) and Chortareas et al. (2016) also find that elections have negative effect on the budget balance through the decrease of local tax collection and the increase of municipal expenditures. Alesina and Paradisi (2017) provide evidence that municipalities in Italy choosing lower tax rate when it is close to election times. Further, Alesina and Paradisi (2017) find that political budget cycles stronger when number of contestant are higher. Aidt and Mooney (2014) find that local government use their 
discretionary to lower tax and save administration cost when the right to vote and obligation to pay taxes are link. Local government use their discretion to increase their chances to win the election. Moreover, they show that before elections, opportunistic incumbents change the composition expenditures toward observable investment items, such as construction of overpasses and street works. They also find identified increases in government expenditures in election years, especially investment expenditures, while Drazen and Eslava (2010) find that infrastructure spending increases prior to election year. Further, Balaguer-Coll et al. (2015) find that increases in government spending have positive effect on re-election prospect.

For discretionary expenditures category, Ritonga and Alam (2010) investigated the allocation of donation (hibah) and social assistance (dana bantuan sosial) expenditures between incumbent and nonincumbent candidates and found that the allocation of donation and social assistance expenditure in incumbent regions during the elections year was higher than prior the elections. Sjahrir et al. (2013) also find significant increase of discretionary budget in election year, and that the political budget cycles are significantly stronger when incumbents run for reelection. On the other hand, Winoto and Falikhatun (2015) find no indication of misuse of grant and social aid before the local election in 2015.

The underline assumption on the theoretical framework of political budget cycle is that an incumbent's reelection chances can be increased by expansionary fiscal policy in general, and in election years in particular (Brender \& Drazen, 2008). A good economic performance can help boosting incumbent's reelection prospects to the extent that expansionary fiscal policy can be used to manipulate macroeconomic outcomes and provide high growth, which signal competence and in turn gains votes for the incumbents. Rogoff (1990) argues that expansionary fiscal policy during election years could lead electorates to vote for incumbents who produce them because it signals high competence.

Veiga and Veiga (2007) provide evidence that elections year have negative effect on the budget balance through the decrease of local tax collection (Alesina \& Paradisi, 2017; Klein \& Sakurai, 2015; Sakurai $\&$ Menezes-Filho, 2011) and the increase of municipal expenditures. Moreover, they show that before elections, opportunistic incumbents change the composition expenditures toward observable investment items, such as construction of overpasses and street works (Chortareas et al., 2016). This study expect that election year is negatively related to the budget balance. Therefore the first hypothesis is

$H_{l}$ : Election year has negative impacts on budget balance.

Rogoff and Sibert (1988) explains the existence of political budget cycles with rational electorates who suffer from asymmetric information regarding the competencies of elected officials. In this context, incumbents would engage in electoral cycles by manipulating economic policy variables, such as taxes and government expenditures, to produce a given level of public services with a lesser amount of revenue as a way to signal competence to electorates.

Vergne (2009), using cross country sample, find evidence that election-year public spending shifts toward more visible current expenditures, in particular wages and subsidies. In line with that, other study focusing on the analysis of local units (Aidt \& Mooney, 2014; Akhmedov \& Zhuravskaya, 2004; Drazen \& Eslava, 2010; Galli \& Rossi, 2002; Veiga \& Veiga, 2007) identify decreases in budget balance and increases in total expenditures and various spending category such as health care, educational, and road construction in election years. Therefore in this study, election year is expected to have positive relation to expenditures. This study investigates total expenditures, investment expenditure, and discretionary 
expenditure such as donation expenditures, social assistance expenditures and financial assistance expenditures. Thus the second hypothesis is.

$H_{2}$ : Election year has positive impacts on expenditures.

It is expected that election year have positive effect on investigates total expenditures, investment expenditure, and discretionary expenditure such as donation expenditures, social assistance expenditures and financial assistance expenditures.

\section{RESEARCH METHOD}

\subsection{Population and Sample}

Population in this study is all districts and municipalities in Indonesia. The sampling method used is purposive sampling to exclude the newly constructed districts and municipalities as results of regional expansion, districts and municipalities that implement delayed election, and for which data are incomplete. This study utilizes a panel data set of public spending and deficits of districts and municipalities in Indonesia which held direct local elections over the period 2010-2014.

From the purposive sampling, the number of districts and municipalities observed are 451 districts. This study use secondary data of local government's budget, social and demographic regional data from 2010-2014.

\subsection{Operational Definition}

i. $\quad$ Budget Balance (Y1)

Budget balance is the difference between revenue and expenditure that works as an indicator of financial health. An exceed in expenditures to revenue is called deficit, while the revenue that exceed expenditures is called surplus. In cases where government identify budget deficit, current expenses exceed the amount of income being received through standard operations. Budget Balance is expressed in percentage of regional Gross Domestic Product (Brender \& Drazen, 2008).

\section{ii. $\quad$ Total Expenditures (Y2)}

Government expenditures is the current spending and investment by the government on the provision of social goods and services (health, education, defence, roads, etc.), marketed goods and services (coal, postal services, etc.) and transfer payments (allowance, pensions, etc.). Government expenditure is financed by taxation and borrowing. Total Expenditures include all government consumption, investment, and transfer payments. Total Expenditures are expressed in natural logarithm (Schneider, 2010).

\section{iii. $\quad$ Investment Expenditures (Y3)}

Investment expenditures is government spending on acquisition of goods and services intended to create future benefits, such as infrastructure investment or research spending. Investment Expenditures are expressed in natural logarithm. 


\section{iv. $\quad$ Discretionary Expenditures $(Y 4, Y 5, Y 6)$}

Discretionary expenditures are government's discretionary spending items of local head to provide financial assistance or to finance small scale programs benefitting core constituencies. These spending include donations (hibah), social assistance (bantuan sosial), and financial assistance (bantuan keuangan) expenditures.

Donation Expenditures (Y4) are donation in the form of money/goods or services from the local government to government or other regional governments, regional government's companies, communities, and community organizations, which have specific use allocation, is not mandatory and not binding, and not continuously given, that aim to support the implementation of local government affairs.

Social Assistance Expenditures (Y5) are social assistance in the form of money/goods from the local government to individual, family, groups and/or communities that are noncontinuous and selectively given that aim to protect from the possibility of social risk.

Financial Assistance Expenditures (Y6) are financial assistance in the form of money/goods or services from the local government to other local governments or villages that aim to address the fiscal gap or assist in the implementation of government affairs.

All the discretionary expenditures are expressed in natural logarithm.

\section{v. Election Year $(X 1)$}

To capture opportunistic election cycles, this study follows Chortareas et al. (2016) where the election variables takes the timing of an election year. It takes the value of one in election years and zero otherwise.

\section{vi. Regional Political Connection (X2)}

In term of the political alignment with local and central parliament, Sakurai and Menezes-Filho (2011) find evidence that budget balance seems to be lower when the local mayor and the President are members of the same political coalition. However, in Indonesian political sphere, the 1999 regional autonomy laws has enhanced the position of the local parliament assemblies (DPRD) by giving them power to elect and hold local government heads accountable, to initiate and promulgate statutes and regulation, and to approve budgets (Rasyid, 2003). This transfer of power allow local parliament to gain substantive responsibility from the local government. Even now, after the transition of direct election for local government head, local parliament still emerged as the new local power-holders.

Therefore, the Regional Political Connection variable used in this study is the regional political alignment between local governments' heads and the local parliament party supporting them. It takes the value of the percentage of political parties or party coalition which support incumbent candidates for the election.

\section{vii. $\quad$ Tenure $(X 3)$}

Chortareas et al. (2016) suggests that tenure might significant effect on local finances. It is expected that tenure have positive effect on political budget cycles because incumbent with longer year have more 
knowledge on the budget process. However, their study in Greece municipalities did not find any effect of years as office-holder to the political budget cycles. To capture the effect of prolonged incumbency in this study, we also use variable Tenure that takes the value of the year of current local government's head in office.

\subsection{Control Variables}

This study use control variables suggested by Sjahrir et al. (2013) and Klomp and De Haan (2013b). The cost of maintaining a functioning administration depends on the characteristics of the district in terms of possible scale economy, so this study controls for Number of Villages. Additionally, higher Unemployment Rate is argued to increase government spending on social security and decrease revenues, and hence raise the budget deficit.

\section{ANALYSIS}

This study uses a panel data set from 451 districts and municipalities in Indonesia which held direct local elections over the period of 2010-2014. Descriptive statistics are provided in Table 1.

Table 1: Descriptive Statistics

\begin{tabular}{ccccc}
\hline \hline Variables & Mean & Std. Deviation & Min. & Max. \\
\hline Budget Balance (\% of Regional GDP) & $-0,010$ & 0,031 & $-0,568$ & 0,184 \\
Total Expenditures* & 11,881 & 0,239 & 10,764 & 12,900 \\
Investment Expenditures* & 11,219 & 0,292 & 0,000 & 12,532 \\
Donation Expenditures* & 9,871 & 1,574 & 0,000 & 11,641 \\
Social Assistance Expenditures* & 9,666 & 1,422 & 0,000 & 11,397 \\
Financial Assistance Expenditures* & 9,302 & 2,893 & 0,000 & 11,693 \\
Election Year & 0,166 & 0,372 & 0,000 & 1,000 \\
Number of Villages (in 100) & 1,602 & 1,192 & 0,130 & 8,620 \\
Unemployment Rate (District Level) & 6,106 & 2,278 & 1,830 & 14,970 \\
Tenure (Years as Mayors) & 3,691 & 2,596 & 0,000 & 9,000 \\
Regional Political Connection & 0,042 & 0,132 & 0,000 & 0,933 \\
\hline \hline
\end{tabular}

Note: $*$ in per capita natural logarithm.

To examine the relation between election year and fiscal policy, this study utilizes a model of electoral budget cycles from Sjahrir et. al. (2013). Possible political budget cycle effects are captured by dummies for the two pre-election years and the election years (Election-2, Election-1, and Election). The model is specified as follow:

$y_{i j t}=\alpha+\gamma$ Elections $_{i(t-2)}+\gamma$ Elections $_{i(t-1)}+\gamma$ Elections $_{i t}+\delta X_{i k t}+n_{i}+u_{i j t}$

The variable $y_{i j t}$ denotes one of the $j$ fiscal indicator in municipality $i$ at time $t, X_{i k t}$ is a vector of $k$ control variables that includes a number of economic, demographic, and political variables, Elections $s_{i t}$ is a dummy variable capturing the electoral effect. The term $n_{i}$ represent the unobserved municipality specific effects and and $u_{i j t}$ represent error term. 


\section{RESULT AND DISCUSSION}

\subsection{Correlation Analysis}

Correlation analysis is used to determine the relationship between two variables along with the direction of the relationship. Correlation coefficient indicates the magnitude of the relationship between two variables. The result of correlation analysis is presented in Table 2.

\subsection{Panel Data Regression Result and Hypothesis Testing}

Table 3: Panel Data Regression Result: Fixed Effect

\begin{tabular}{ccccccc}
\hline \hline Variables & Balance & TotExp & InvExp & DonExp & SocAssist Exp & FinanAssistExp \\
\hline Constant & -0.0046 & $11.9591^{* * *}$ & $11.3304 * * *$ & $10.6210^{* * *}$ & $9.7531 * * *$ & $10.9264 * *$ \\
& $(0,4601)$ & $(0,0000)$ & $(0,0000)$ & $(0,0000)$ & $(0,0018)$ & $(0,0044)$ \\
Election-2 & -0.0009 & -0.0058 & -0.0061 & -0.0310 & -0.4243 & -0.0773 \\
& $(0,2804)$ & $(0,1308)$ & $(0,2554)$ & $(0,3356)$ & $(0,0000)$ & $(0,2828)$ \\
Election-1 & 0.0004 & $0.0071^{*}$ & $-0.0150 * *$ & 0.0494 & 0.0638 & 0.1619 \\
& $(0.3968)$ & $(0,0750)$ & $(0,0451)$ & $(0,2392)$ & $(0.2690)$ & $(0,1032)$ \\
Election & $\mathbf{- 0 . 0 0 6 6 * *}$ & $\mathbf{0 . 0 1 6 0} * *$ & -0.0184 & $\mathbf{0 . 3 3 1 1} * *$ & $\mathbf{- 0 . 3 5 9 5 * *}$ & $\mathbf{0 . 7 1 1 5} * *$ \\
& $(0,0072)$ & $(0,0475)$ & $(0,1420)$ & $(0,0070)$ & $(0,0366)$ & $(0,0021)$ \\
Villages & -0.0010 & 0.1100 & 0.1437 & -0.2516 & -0.8929 & -0.2635 \\
& $(0,4866)$ & $(0,1354)$ & $(0.2112)$ & $(0,4290)$ & $(0,3348)$ & $(0,4595)$ \\
Unemploy. & -0.0004 & $-0.0442 * * *$ & $-0.0569 * * *$ & $-0.0485 *$ & $0.2239 * *$ & $-0.2340 * * *$ \\
& $(0,2548)$ & $(0,0000)$ & $(0,0000)$ & $(0,0635)$ & $(0,0000)$ & $(0,0000)$ \\
Tenure & -0.0001 & $\mathbf{0 . 0 1 3 0 * * *}$ & $0.0140 * * *$ & 0.0023 & -0.0048 & $\mathbf{0 . 0 8 7 1} * *$ \\
& $(0,3974)$ & $(0,0000)$ & $(0,0000)$ & $(0.4553)$ & $(0,4366)$ & $(0,0096)$ \\
RegPolConn & $\mathbf{0 . 0 1 5 9 * *}$ & $\mathbf{- 0 . 0 3 1 9 *}$ & -0.0469 & 0.1793 & 0.6278 & $\mathbf{- 1 . 3 7 4 6 * *}$ \\
& $(0,0088)$ & $(0,0890)$ & $(0,1344)$ & $(0.2952)$ & $(0,1025)$ & $(0,0126)$ \\
\hline Obs. & 1804 & 1804 & 1804 & 1804 & 1804 & 1804 \\
$\mathrm{R}^{2}$ & 0.6995 & 0.9299 & 0.8362 & 0.4392 & 0.3894 & 0.5923 \\
Adjusted R ${ }^{2}$ & 0.5975 & 0.9061 & 0.7806 & 0.2488 & 0.1821 & 0.4539 \\
F-stat & 6.8567 & 39.0939 & 15.0368 & 2.3067 & 1.8784 & 4.2794 \\
Prob(F-stat) & 0.0000 & 0.0000 & 0.0000 & 0.0000 & 0.0000 & 0.0000 \\
\hline \hline
\end{tabular}

Note: Election(-2)=Two Years Before Election Year; Election(-1)=One Year Before Election Year; Election=Election Year (Dummy variables, 1 for election year and 0 for non-election year); Villages=Number of Villages (in 100); Unemploy.=Unemployment Rate (District Level); Tenure=Years as Mayor; RegPolConn=Regional Political Connection (Percentage of political parties or party coalition that support incumbent candidates for re-election). *, **, ***=significant at $10 \%$, $5 \%$, dan $1 \%$.

From the panel data regression result, we find evidence that the relationship between dependent variable Budget Balance and Election Year is significant and negative. The result table shows that Election Year has negative influence to Budget Balance. Thus the first hypothesis is supported. This finding provide similar results documented in other relevant studies (Chortareas et al., 2016; Drazen \& Eslava, 2010; Klein \& Sakurai, 2015; Klomp \& De Haan, 2013b; Sakurai \& Menezes-Filho, 2011; Schneider, 2010; Veiga \& Veiga, 2007). In terms of political alignment, the coefficient regarding regional political connection to local parliament is significant, suggesting the influence of regional political connection to Budget Balance. 


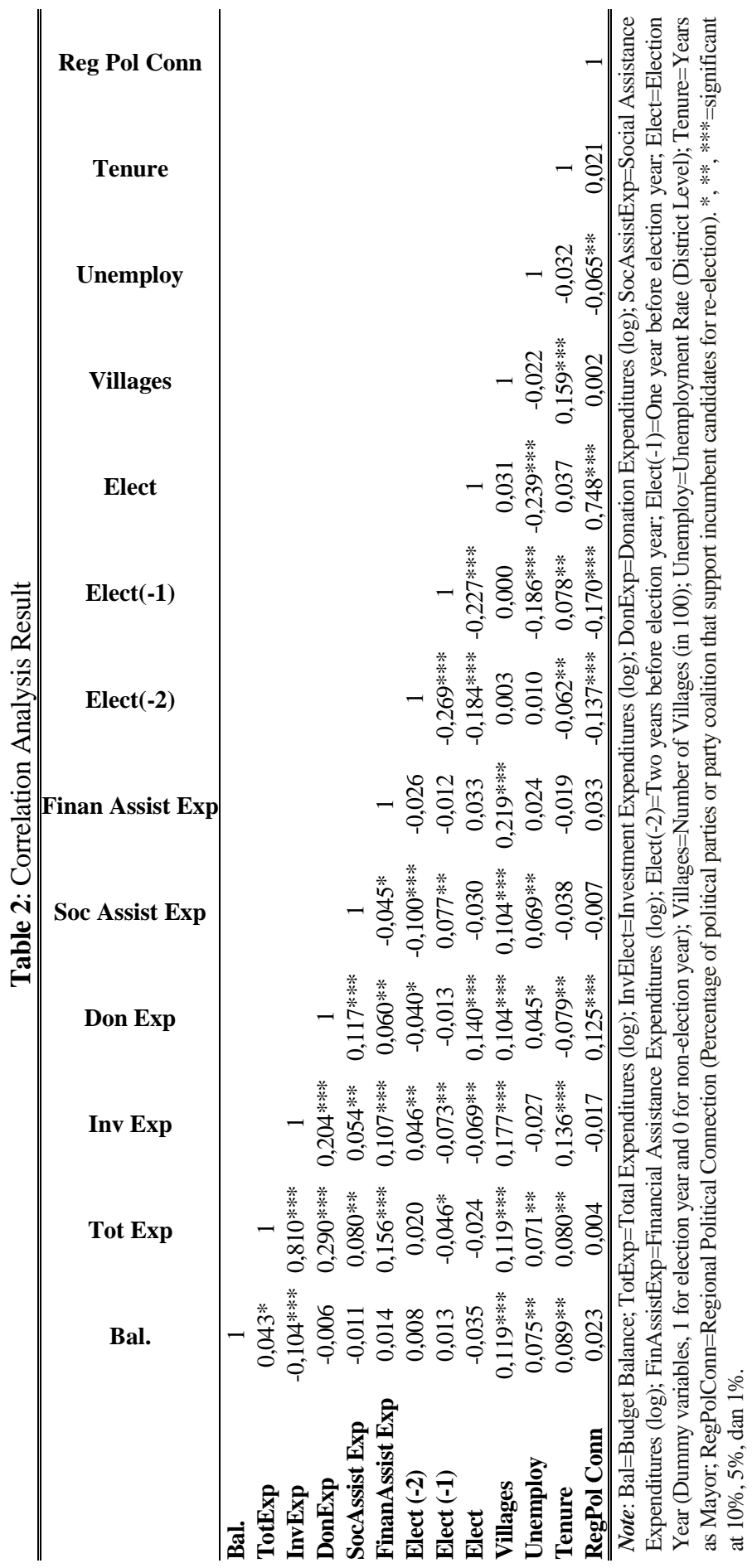


We also find evidence that the relationship between dependent variable Total Expenditures and Election Year is positive. This result supports the notion that elections have a positive effect on the Total Expenditures through the increase of municipal expenditures, especially expenditures that are highly visible to electorate. The result also suggest that years as mayors (Tenure) positively affect Total Expenditures. Chortareas et al. (2016) suggests that a prolonged incumbency may be expected to affect the magnitude of political budget cycles. An incumbent who has served for a prolonged period may have greater ability to manipulate local finances, as he become familiar with the relevant budgetary process or incentives for pre-electoral manipulation.

On the investment expenditures, Veiga and Veiga (2007) and Chortareas et al. (2016) identified increases in government expenditures in election years, especially investment expenditures. On the other hand, Sakurai and Menezes-Filho (2011) find that investment expenditures tend to decrease in election year. They argue that it is because investment expenditures generally take time to produce visible outcomes. In this study, we find no significant effect of Election Year to Investment Expenditures. Hypothesis testing result shows that Election Year doesn't have significant effect to Investment Expenditures. However, there is a significant decrease of Investment Expenditures prior to election year.

According to study by Sjahrir et al. (2013), donations expenditures have display a strongly cyclical behavior in direct elections, especially if the incumbent running for reelection. Hypothesis testing result shows that Election Year has positive effect on Donation Expenditures.

On the other hand, we find that Election Year does have significant effect to Social Assistance Expenditures. However, the direction of influence is negative rather than positive. This could be because of the change in composition of government spending, which choose to spend the budget on other spending like donation or financial assistance expenditures.

The study also positive relationship between Financial Assistance Expenditures and Election Year. Election year has increase the financial expenditure. There is indication that financial expenditure is increase around the election year. We also find positive relationship between Tenure (years as mayors) and Financial Assistance Expenditures. This suggests that prolonged incumbency may increase the magnitude of political budget cycles.

\subsection{Robustness Check}

For robustness purposes this study considers the random effect model (Table 4) and the interaction effect of election year with candidate's incumbency (Table 5).

In random effect model, the results are consistent with those of fixed effect model. The election year is again significant to Budget Balance, Total Expenditures, Donation Expenditures, and Financial Assistance Expenditures, while it is not significant to Investment Expenditures. The election year is also significant to Social Assistance Expenditures, with the negative direction rather than positive.

We also interract Election Year variable with dummy variables Incumbency, which takes the value of one when the incumbents run for reelection and zero otherwise. The results show that the interraction of Election Year and Incumbency is insignificant except in the case of Total Expenditures and Investment Expenditures. Even then, the direction of the coefficient of both Total Expenditures and Investment Expenditures are negative rather than positive. 


\section{CONCLUSION}

This study aimed to examines the presence of these politically induced and electorally motivated economic policy in local government budget of Indonesian municipalities. The evidence produced shows an opportunistic PBC pattern in the budget balance, total expenditures, donation expenditures, and financial assistance expenditures.

Table 4: Robustness Check: Random Effect Model

\begin{tabular}{ccccccc}
\hline \hline Variables & Balance & TotExp & InvExp & DonExp & SocAssist Exp & FinanAssistExp \\
\hline Constant & $-0,0183$ & 11,9480 & 11,3576 & 9,8506 & 9,2944 & 10,9264 \\
& $(0,000)$ & $(0,0000)$ & $(0,0000)$ & $(0,0000)$ & $(0,0000)$ & $(0,0044)$ \\
Election-2 & 0,0000 & $-0,0029$ & 0,0012 & $-0,0430$ & $-0,4564 * * *$ & $-0,0773$ \\
& $(0,4794)$ & $(0,2848)$ & $(0,4463)$ & $(0,2649)$ & $(0,0000)$ & $(0,2828)$ \\
Election-1 & 0,0010 & 0,0043 & $-0,0193 * *$ & 0,0031 & 0,0779 & 0,1619 \\
& $(0,2160)$ & $(0,1874)$ & $(0,0124)$ & $(0,4808)$ & $(0,2028)$ & $(0,1032)$ \\
Election & $\mathbf{- 0 , 0 0 6 0 * *}$ & $\mathbf{0 , 0 1 4 6 *}$ & $-0,0207$ & $\mathbf{0 , 2 6 4 8} * *$ & $\mathbf{- 0 , 4 4 5 7 * *}$ & $\mathbf{0 , 7 1 1 5 * *}$ \\
& $(0,0109)$ & $(0,0616)$ & $(0,1082)$ & $(0,0146)$ & $(0,0062)$ & $(0,0021)$ \\
Villages & $0,0031^{* *}$ & $0,0826 * * *$ & $0,0519 * * *$ & $0,0953 * *$ & $0,0678^{* *}$ & $-0,2635$ \\
& $(0,0014)$ & $(0,0000)$ & $(0,0000)$ & $(0,0006)$ & $(0,0425)$ & $(0,4595)$ \\
Unemploy. & 0,0004 & $-0,0347 * * *$ & $-0,0370 * * *$ & 0,0045 & $0,0561 * *$ & $-0,2340 * *$ \\
& $(0,1836)$ & $(0,0000)$ & $(0,0000)$ & $(0,3832)$ & $(0,0036)$ & $(0,0000)$ \\
Tenure & $0,0004 *$ & $\mathbf{0 , 0 1 3 1 * * *}$ & $\mathbf{0 , 0 1 5 0} * * *$ & $\mathbf{- 0 , 0 1 7 1 *}$ & $\mathbf{- 0 , 0 2 9 6} * *$ & $\mathbf{0 , 0 8 7 1 * *}$ \\
& $(0,0961)$ & $(0,0000)$ & $(0,0000)$ & $(0,0876)$ & $(0,0468)$ & $(0,0096)$ \\
RegPolConn & $\mathbf{0 , 0 1 7 0 * *}$ & $-0,0263$ & $-0,0302$ & $\mathbf{0 , 4 1 3 8 *}$ & $\mathbf{0 , 6 5 1 6 *}$ & $\mathbf{- 1 , 3 7 4 6 * *}$ \\
& $(0,0048)$ & $(0,1320)$ & $(0,2350)$ & $(0,0906)$ & $(0,0756)$ & $(0,0126)$ \\
\hline Obs. & 1804 & 1804 & 1804 & 1804 & 1804 & 1804 \\
$\mathrm{R}^{2}$ & 0,0126 & 0,2365 & 0,1386 & 0,0269 & 0,0262 & 0,5923 \\
Adjusted $\mathrm{R}^{2}$ & 0,0087 & 0,2335 & 0,1353 & 0,0231 & 0,0224 & 0,4539 \\
F-stat & 3,270 & 79,4694 & 41,2979 & 7,0806 & 6,9042 & 4,2792 \\
Prob(F-stat) & 0,0019 & 0,0000 & 0,0000 & 0,0000 & 0,0000 & 0,0000 \\
\hline \hline
\end{tabular}

Note: Election(-2)=Two Years Before Election Year; Election(-1)=One Year Before Election Year; Election=Election Year (Dummy variables, 1 for election year and 0 for non-election year); Villages=Number of Villages (in 100); Unemploy.=Unemployment Rate (District Level); Tenure=Years as Mayor; RegPolConn=Regional Political Connection (Percentage of political parties or party coalition that support incumbent candidates for re-election). *, **, ***=significant at $10 \%$, $5 \%$, dan $1 \%$.

The result suggest that there is an increase in local budget deficit in election years, similar to those reported by Veiga and Veiga (2007) and Drazen and Eslava (2010), who find that local governments systematically change the composition of expenditures in election years. Total expenditures also seem to increase during the electionyear, along with donation and financial assistance expenditures. This result supports the notion that elections have a positive effect on the government expenditures through the increase of municipal expenditures, especially expenditures that are highly visible to electorate. The result also suggest that years as mayors (tenure) has positive effect on the increase of total expenditures.

On the other hand, we find no significant effect of Election Year to Investment Expenditures. However, there is a significant decrease of Investment Expenditures prior to election year. We also find that Election Year does have significant effect to Social Assistance Expenditures, but the direction of influence is negative rather than positive. This could be because of the change in composition of government spending, which choose to spend the budget on other spending such as donation or financial assistance expenditures. 


\subsection{Suggestion}

This study has some limitations in the amount of observation, in which not all districts and municipalities in Indonesia are included in this study. Some districts and municipalities in Indonesia excluded from samples are the newly constructed districts and municipalities as results of regional expansion, districts and municipalities that implement delayed election, and for which data are incomplete.

Based on the limitation above, it is recommended for further research to expand its observation districts and municipalities. It is interesting to investigate how political budget cycles in the newly constructed district and municipalities. Additionally, further research can add more fiscal policy variables to further studying the depth of macroeconomic policy manipulation in Indonesia political sphere.

Table 5: Robustness Check: Incumbency

\begin{tabular}{ccccccc}
\hline \hline Variables & Balance & TotExp & InvExp & DonExp & SocAssist Exp & FinanAssistExp \\
\hline Constant & $-0,0041$ & 11,9524 & 11,3204 & 10,6238 & 9,7946 & 10,8801 \\
& $(0,4636)$ & $(0,0000)$ & $(0,0000)$ & $(0,0000)$ & $(0,0018)$ & $(0,0044)$ \\
Election-2 & $-0,0010$ & 0,0037 & $-0,0029$ & $-0,0319$ & $-0,4377$ & $-0,0623$ \\
& $(0,2530)$ & $(0,2405)$ & $(0,3788)$ & $(0,3323)$ & $(0,0000)$ & $(0,3228)$ \\
Election-1 & 0,0002 & $\mathbf{0 , 0 1 0 1 * *}$ & $-0,0105$ & 0,0481 & 0,0451 & $\mathbf{0 , 1 8 2 7} *$ \\
& $(0,4480)$ & $(0,0214)$ & $(0,1202)$ & $(0,2480)$ & $(0,3338)$ & $(0,0800)$ \\
Election & $\mathbf{- 0 , 0 0 7 4 * *}$ & $\mathbf{0 , 0 2 8 7 * *}$ & 0,0006 & $\mathbf{0 , 3 2 5 8 * *}$ & $\mathbf{- 0 , 4 3 8 4} * *$ & $\mathbf{0 , 7 9 9 6 * *}$ \\
& $(0,0053)$ & $(0,0024)$ & $(0,4861)$ & $(0,0119)$ & $(0,0204)$ & $(0,0013)$ \\
Election*Incumbent & 0,0028 & $\mathbf{- 0 , 0 4 5 7 * *}$ & $\mathbf{- 0 , 0 6 8 4 *}$ & 0,0190 & 0,2837 & $-0,3169$ \\
& $(0,2262)$ & $(0,0002)$ & $(0,0016)$ & $(0,4584)$ & $(0,1472)$ & $(0,1720)$ \\
Villages & $-0,0007$ & 0,1061 & 0,1378 & $-0,2500$ & $-0,8686$ & $-0,2904$ \\
& $(0,4898)$ & $(0,1430)$ & $(0,2200)$ & $(0,4295)$ & $(0,3390)$ & $(0,4554)$ \\
Unemploy. & $-0,0005$ & $-0,0435 * * *$ & $-0,0558^{* * *}$ & $-0,0488 *$ & $0,2195 * * *$ & $-0,2290^{* *}$ \\
& $(0,2345)$ & $(0,0000)$ & $(0,0000)$ & $(0,0632)$ & $(0,000)$ & $(0,0000)$ \\
Tenure & $-0,0002$ & $\mathbf{0 , 0 1 4 8} * * *$ & $\mathbf{0 , 0 1 6 6} * * *$ & 0,0015 & $-0,0158$ & $\mathbf{0 , 0 9 9 4 *}$ \\
& $(0,3108)$ & $(0,0000)$ & $(0,0000)$ & $(0,4715)$ & $(0,3096)$ & $(0,058)$ \\
RegPolConn & $\mathbf{0 , 0 1 3 2 * *}$ & 0,0141 & 0,0219 & 0,1602 & 0,3427 & $\mathbf{- 1 , 0 5 6 1 *}$ \\
& $(0,0428)$ & $(0,3000)$ & $(0,3248)$ & $(0,3367)$ & $(0,2721)$ & $(0,0656)$ \\
\hline Obs. & 1804 & 1804 & 1804 & 1804 & 1804 & 1804 \\
$\mathrm{R}^{2}$ & 0,6996 & 0,9306 & 0,8372 & 0,4392 & 0,3899 & 0,5926 \\
Adjusted $\mathrm{R}^{2}$ & 0,5974 & 0,9070 & 0,7819 & 0,2482 & 0,1821 & 0,4539 \\
F-stat & 6,8407 & 39,3734 & 15,1100 & 2,3000 & 1,8769 & 4,2715 \\
Prob(F-stat) & 0,0000 & 0,0000 & 0,0000 & 0,0000 & 0,0000 & 0,0000 \\
\hline \hline
\end{tabular}

Note: Election(-2)=Two Years Before Election Year; Election(-1)=One Year Before Election Year; Election=Election Year (Dummy variables, 1 for election year and 0 for non-election year); Incumbent=Candidate's Incumbency (Dummy variable, 1 when the incumbents run for reelection and 0 otherwise; Villages=Number of Villages (in 100); Unemploy.=Unemployment Rate (District Level); Tenure=Years as Mayor; RegPolConn=Regional Political Connection (Percentage of political parties or party coalition that support incumbent candidates for re-election). *, **, ***=significant at $10 \%, 5 \%$, dan $1 \%$.

\section{REFERENCE}

Aidt, T. S., \& Mooney, G. (2014). Voting Suffrage and the Political Budget Cycle: Evidence from the London Metropolitan Boroughs 1902-1937. Journal of Public Economics, 112, 53-71. 
Akhmedov, A., \& Zhuravskaya, E. (2004). Opportunistic Political Cycles: Test in a Young Democracy Setting. The Quarterly Journal of Economics, 119(4), 1301-1338.

Alesina, A., \& Paradisi, M. (2017). Political Budget Cycles: Evidence from Italian Cities. Economics \& Politics, 29(2), 157-177.

Alt, J., Lassen, D. D., \& Wehner, J. (2014). It Isn't Just about Greece: Domestic Politics, Transparency and Fiscal Gimmickry in Europe. British Journal of Political Science, 44(4), 707-716.

Balaguer-Coll, M. T., Brun-Martos, M. I., Forte, A., \& Tortosa-Ausina, E. (2015). Local Governments' Re-election and Its Determinants: New Evidence Based on a Bayesian Approach. European Journal of Political Economy, 39, 94-108.

Brender, A. (2003). The Effect of Fiscal Performance on Local Government Election Results in Israel: 1989-1998. Journal of Public Economics, 87(9), 2187-2205.

Brender, A., \& Drazen, A. (2005). Political Budget Cycles in New Versus Established Democracies. Journal of Monetary Economics, 52(7), 1271-1295.

Brender, A., \& Drazen, A. (2008). How Do Budget Deficits and Economic Growth Affect Reelection Prospects? Evidence from a Large Panel of Countries. The American Economic Review, 98(5), 2203-2220.

Chortareas, G., Logothetis, V., \& Papandreou, A. A. (2016). Political Budget Cycles and Reelection Prospects in Greece's Municipalities. European Journal of Political Economy, 43, 1 - 13.

De Haan, J., \& Klomp, J. (2013). Conditional Political Budget Cycles: A Review of Recent Evidence. Public Choice, 157(3-4), 387-410.

Drazen, A., \& Eslava, M. (2010). Electoral Manipulation Via Voter-friendly Spending: Theory and Evidence. Journal of Development Economics, 92(1), 39-52.

Galli, E., \& Rossi, S. P. (2002). Political Budget Cycles: The Case of the Western German Länder. Public Choice, 110(3), 283-303.

Gunawan, A. H., \& Siregar, R. Y. (2009). Survey of Recent Developments. Bulletin of Indonesian Economic Studies, 45(1), 9-38.

Klein, F. A., \& Sakurai, S. N. (2015). Term Limits and Political Budget Cycles at The Local Level: Evidence from a Young Democracy. European Journal of Political Economy, 37, 21-36.

Klomp, J., \& De Haan, J. (2013a). Do Political Budget Cycles Really Exist? Applied Economics, 45(3), 329-341.

Klomp, J., \& De Haan, J. (2013b). Political Budget Cycles and Election Outcomes. Public Choice, 157(1-2), 245-267.

Labonne, J. (2016). Local Political Business Cycles: Evidence from Philippine Municipalities. Journal of Development Economics, 121, 56-62.

Nordhaus, W. D. (1975). The Political Business Cycle. The Review of Economic Studies, 42(2), 169-190.

Persson, T., \& Tabellini, G. E. (2002). Do electoral cycles differ across political systems? Innocenzo Gasparini Institute for Economic Research, Working Paper 232.

Rasyid, M. R. (2003). Regional Autonomy and Local Politics in Indonesia. In E. Aspinall \& G. Fealy (Eds.), Local power and politics in Indonesia (pp. 63-72). Singapore: Institute of Southeast Asian Studies.

Ritonga, I. T., \& Alam, M. I. (2010). Apakah Incumbent Memanfaatkan Anggaran Pendapatan dan Belanja Daerah (APBD) Untuk Mencalonkan Kembali Dalam Pemilihan Umum Kepala Daerah (Pemilukada). Proceedings of the Simposium Nasional Akuntansi 13 (pp. 1-25). Purwokerto, Indonesia: Universitas Jenderal Soedirman.

Rogoff, K. (1990). Equilibrium Political Budget Cycles. The American Economic Review, 80(1), 21-36.

Rogoff, K., \& Sibert, A. (1988). Elections and Macroeconomic Policy Cycles. The Review of Economic Studies, 55(1), 1-16. 
Sakurai, S. N., \& Menezes-Filho, N. (2011). Opportunistic and Partisan Election Cycles in Brazil: New Evidence at the Municipal Level. Public Choice, 148(1), 233-247.

Schneider, C. J. (2010). Fighting with One Hand Tied Behind the Back: Political Budget Cycles in the West German States. Public Choice, 142(1), 125-150.

Shi, M., \& Svensson, J. (2006). Political Budget Cycles: Do They Differ Across Countries and Why? Journal of Public Economics, 90(8), 1367-1389.

Sjahrir, B. S., Kis-Katos, K., \& Schulze, G. G. (2013). Political Budget Cycles in Indonesia at the District Level. Economics Letters, 120(2), 342-345.

Veiga, L. G., \& Veiga, F. J. (2007). Political Business Cycles at the Municipal Level. Public Choice, $131(1), 45-64$.

Vergne, C. (2009). Democracy, Elections and Allocation of Public Expenditures in Developing Countries. European Journal of Political Economy, 25(1), 63-77.

Winoto, A. H., \& Falikhatun, F. (2015). Indikasi Penyalahgunaan Discretionary Fund dalam Anggaran Pendapatan dan Belanja Daerah Menjelang Pemilukada 2015. Jurnal Akuntansi dan Keuangan Indonesia, 12(1), 75-91. 